\title{
Digital Technologies in Tax and Civil Legal Relations
}

\author{
Alexandr Gogin ${ }^{1}$ Anna Fedorova ${ }^{1, *}$ Yulia Smolyak $^{1}$ \\ ${ }^{1}$ Togliatti State University, Togliatti 445020, Russian Federation \\ *Corresponding author.Email: an fedorova@mail.ru
}

\begin{abstract}
In a very short period from a historical point of view, information and methods of its dissemination have acquired the status of one of the most important factors in modern social life. At present, the relevant innovations are actively supporting the multifaceted activities of state authorities and local self-government; the country's armed forces and law enforcement agencies; economic subjects of different forms of ownership and organizational structure; political parties and movements; public and professional associations; creative unions and associations; everyday life of ordinary citizens.

Therefore, in the proposed article, the subject of research is the provisions of separate legislative acts that officially establish the procedure for applying IT, based on the intensive and large-scale use of computer technology, communications and telecommunication systems.

The relevance of the study is due to the fact that on the verge of two centuries, these innovations actually made a revolutionary revolution not only in the economy, politics and culture, but also in public consciousness, morality and forms of human behavior. At the same time, the existing legislative provisions require periodic adjustments and clarifications.
\end{abstract}

Keywords: State, law, tax, technology, digital economy, interest, activity, area, information.

\section{INTRODUCTION}

There is no longer any doubt that the fact that not only the effectiveness of the decisions made, but also the final results of the functioning of all the above formations, the realization of the interests of individual individuals and other users of the systems of national and international information support depend on the qualitative and operational use of these technologies. At the same time, the introduction of information technologies (hereinafter IT) into social circulation urgently and objectively required their proper regulatory and legal registration.

The starting point of the scientific research carried out was the content of Art. 5 of the Federal Law of the Russian Federation of July 27, 2006 No. 149-FZ (as amended on June 8, 2020) "On Information, Informatization and Protection of Information" [1], which states that the named phenomenon can be the object of public, civil and legal relationship. At the same time, the authors took into account; certain requirements of the Tax Code of the Russian Federation, the Civil Code of the Russian Federation and other laws. In the final part of the article, conclusions are formulated related to the need for a more in-depth use of IT in various social processes.

In the Russian Federation, the legal basis for the introduction of IT into the daily practice of social relationships and business contacts of the widest and most diverse range was laid by the Federal Law of the Russian Federation of January 10, 2002 No. 1-FZ "On electronic digital signature" [2].
Following it, a revised version of the Federal Law of the Russian Federation of July 27, 2006 No. 149-FZ (as amended on June 8, 2020) "On Information, Informatization and Information Protection" (hereinafter Law No. 149-FZ) [1] was promulgated. Here it should be emphasized right away that in the specified act, among others, two concepts are formulated that run like a red thread through the entire content of this publication.

Thence, according to Art. 2, information is information (messages, data) regardless of the form of their presentation. In turn, information technologies are defined as processes, methods of searching, collecting, storing, processing, providing, distributing information, as well as ways of implementing the corresponding processes and methods.

Against this background, our attention was drawn to the content of Art. 5 of the aforementioned Law, since it emphasizes that information can be the object of public, civil and other legal relations (italics are the author's). It is this message that is one of the significant aspects underlying the scientific research carried out.

The first aforementioned law played a well-known positive role at the initial stage of the formation of information technologies. However, the practice of its application revealed the presence of significant shortcomings. In particular, they resulted in well-grounded claims from users. These included, first of all, subjects of various types of economic activity, officials of state executive authorities and local self-government bodies, entrepreneurs and ordinary citizens.

Ultimately, this was one of the reasons for the adoption of the new, supplemented and improved Federal 
Law of the Russian Federation dated April 6, 2011 No. 63-FZ (as amended on June 8, 2020) "On electronic signature", and the previous one lost its legal force [3].

It should be noted that from a literary point of view, the wording enshrined in the law seems to be very unfortunate due to the overload of the basic term. The specified signature is understood as information in electronic form, which is attached to other information in electronic form (signed information) or otherwise associated with such information and which is used to identify the person who signs the information.

It should be emphasized that the cardinal difference between electronic documents and the usual, historically established paper samples is characterized by the specific features of IT and completely different than before, methods of fixing the relevant data:

a) There is no rigid, direct connection between the document and its material medium;

b) At the same time, the internal content of the electronic document and its external design retain and reflect the established parameters of the presentation of information inherent in paper media;

c) The preparation of the text of electronic documents and the subsequent transfer of information to various interested parties, including authorized government structures, in the overwhelming majority of cases does not require a long-term, special training among wide layers of users.

In fact, the listed acts opened the green light for the consolidation of provisions on the use of IT in everyday practice in the norms of Russian industry legislation. At the present time, these innovations have officially become integral elements of the functioning of state authorities and local self-government; structures with oversight and control powers; acquired the status of mandatory components in the activities of all domestic economic entities, regardless of their production, commercial or other purpose; consistently enter the everyday life of ordinary citizens.

\section{MATERIALS AND METHODS}

During the preparation of the article, the methodological basis was a number of techniques of modern knowledge. General scientific: dialectical and comparative legal methods, analysis and synthesis, as well as a private scientific formal legal approach.

Firstly, this is due to the fact that only the dialectical method is the foundation on which scientific research is based, where the main goal is the objective study of direct initial data. From the standpoint of materialistic dialectics, every socially significant event or phenomenon is intended to be studied in movement and development; in conjunction with other concomitant factors that are of fundamental importance.

Secondly, the appeal to the comparative legal method allowed the authors of the publication to reasonably comprehend the content of laws that are public and private; consider their structure and internal structure of specific legal conditions. For example, the rules of Russian tax legislation and the proportionality of its relationship with the rights, benefits and interests of individuals acquiring the status of self-employed citizens were compared.

Thirdly, when analyzing the legislative conditions, the unified legal constructions were divided into separate constituent elements, each of which was studied separately. At the same time, their inherent specific features and individual characteristics were subject to careful assessment. In particular, some articles of the RF Tax Code and the RF Civil Code were subjected to such actions. Then, through synthesis, the designated elements of the studied subject were combined into a common whole.

Fourthly, the formal legal approach made it possible to pay due attention to the technique of presenting legal material in certain normative structures. Research practice shows that this type of system for organizing scientific research allows one to formulate the most objective assessments and conclusions, which are the final results of the work carried out and presented in the form of the author's conclusions.

\section{DISCUSSIONS}

All the processes associated with the implementation of IT in various spheres of social life from the very beginning of their inception were and still continue to be under the gaze of Russian scientists and specialists. From a huge block of sources from different years, we will give only a few fairly typical facts.

In particular, as early as 1988, an article by Yershov on the computer literacy of the younger generation and the information culture of society [4, pp. 82-92]. Over the last decade of the last century, publications on relevant topics were regularly published. It is characteristic that even then the prospects for the preparation of the current normative legal acts were discussed. Therefore, at present, almost all monographs and journal articles, one way or another, are based on the provisions of the above-mentioned laws.

For example, Shvetsov in his work touches upon the problems of the formation of the theory and practice of the information society in the world and in Russia [5]. A team of authors under the leadership of Babkina focuses on trends in the development of the economy and indus- 
try in the context of digitalization at the regional and sectoral levels [6]. In turn, the subject of Lapidus raised issues of e-business management and e-commerce [7].

Other researchers analyze narrower topics related to information technology, depending on the goals and objectives of their own scientific research; specialization and areas of professional activity; practical and other multifaceted interests; ideas and socially significant expectations.

In one of the sections of the monograph Burtsev, the main parameters of information processed in the system of tax authorities were formulated in detail [8, pp. 130146]. Bobrov analyzes certain humanitarian aspects of information technology [9, pp. 268-270]. Pisenko and Gasparyan touches upon the problems of legal support of antimonopoly policy in digital financial markets $[10, \mathrm{pp}$. 71-78].

Sannikov and Kharitonova consider the features of digital assets as objects of entrepreneurial turnover [11, pp. 27-34]. Nevskaya and Kondeev focus on the means of legal regulation of electronic commerce in the Eurasian space and the participation of the Russian Federation in it [12, pp. 59-71].

Since robots are becoming actual participants in the digital economy, in the article by Serova discusses the problems of determining their legal nature [13, pp. 2224]. For his part, Nam explores the essence of electronic forms of transactions under the legislation of the European Union and Germany [14, pp. 18-128]. Akhmetov talks about the ways and means of using information technologies in the domestic legal education [15, pp. 7178].

Currently, the unofficial term digitalization has become widespread. It should be noted that the legally enshrined legal definition that characterizes the truly planetary scale of this phenomenon of the 21 st century does not yet exist. The "Strategy for the Development of the Information Society in the Russian Federation for 20172030", approved by Decree of the President of the Russian Federation No. 203 dated May 9, 2017 [16], only describes the digital economy and the ecosystem of the digital economy (hereinafter referred to as the Strategy).

According to Art. 4 of the aforementioned document, the digital economy is defined as an exclusively economic activity, where the key factor of production is digital data, the processing of large volumes and the use of the analysis results of which, in comparison with traditional forms of management, can significantly increase the efficiency of various types of production, technologies, equipment, storage, sale, delivery of goods and services.

In turn, the ecosystem of the digital economy is understood as a partnership of organizations that ensure the constant interaction of their technological platforms, applied Internet services, analytical systems, information systems of state authorities of the Russian Federation, organizations and citizens.

A critical assessment of the above formulations clearly shows that they reflect exclusively the economic aspect of IT application. Meanwhile, all of the above examples of scientific research reveal a very wide range of social spheres, where these innovations are actively introduced and used.

Earlier it was noted that at the legislative level information is officially recognized as an object of public, civil and other legal relations. At the moment, this postulate has not only a theoretical meaning, but is already widely implemented in a practical plane. This is evidenced by the specific content of a number of domestic legislative rules.

As an illustration of purely public legal relations, let us turn to the articles of the Tax Code of the Russian Federation, since it is the tax authorities that implement one of the most significant state functions - the function of taxation. It is inherent in the very nature of taxes in all historical periods of the existence of the state system of organizing society. With its help, the necessary monetary funds are formed and the financial conditions for the state's activity are created in the interests of various social strata and groups of the population.

At the same time, public legal relations deliberately provide for the inequality of the parties, because the main method of implementing the state's internal policy is directives and imperative requirements. In this type of relationship, there are no dispositional principles and the method of agreements is not applied. (Public - from Lat. Publicus - public, open, vowel, not private) [17, 575 p.].

An analysis of the changes and adjustments made to the Tax Code of the Russian Federation in recent years shows that, in comparison with other legislative acts, its content has been supplemented by many clear and detailed norms that consistently determine the procedure for the mandatory use of IT. In fact, the tax legislation has undergone a fairly detailed reform, which is confirmed by three significant circumstances:

a) Since the creation of the Federal Tax Service (FTS), its employees in their activities operated on a huge volume of paper documents, the manual processing of which quickly became costly, ineffective and lost the proper efficiency. Therefore, it was the Federal Tax Service that initiated the active implementation of IT in the sphere of everyday communication with individuals and legal entities: taxpayers;

b) Only with the adoption of laws regulating the procedures for using electronic reporting forms, the information contained in them acquired a full-fledged status 
in the workflow. For example, an electronic digital signature (EDS) of a taxpayer has equal value with a handwritten signature made on paper. Characteristically, he can certify several interconnected documents with one EDS - a package of relevant data transmitted to the tax authorities;

c) In addition, not only in contacts with taxpayers, but also in interaction with other power structures at the federal, regional and local levels, tax authorities and their officials within their powers and within the boundaries established by law, also operate with electronic documents.

Currently, with the use of electronic digital technologies, including the Internet, a virtual reconciliation of taxpayers' reporting documents is widely carried out in order to identify possible discrepancies in calculations with the budget and accounting for tax payments. In the same way, representatives of the tax authorities provide official answers and explanations about the legal conditions and other regulations.

We believe that the active use of IT played an important role in the fact that in 2018 the total tax revenues to the budgets of all levels amounted to 21.3 trillion. rubles, which is $23 \%$ more than in the previous 2017 . If we recall the results of ten years ago, the collection of taxes compared with that reporting period practically doubled [18].

Let us comment on the content of only certain rules of the Tax Code of the Russian Federation, which formulate the requirements for taxpayers on issues related to the use of IT.

It is well known that for the implementation of effective and efficient tax control, the authorized bodies must have at their disposal the necessary information about the amount and timing of payment of taxes and fees that are associated with specific tax periods.

In the most generalized form, reporting is traditionally understood as a system of a certain kind of data on a particular direct object of taxation. The relevant information, expressed in documentary form, is transferred by taxpayers to the Federal Tax Service in the prescribed manner. The main reporting document is the tax return and reliable, objective calculations for all operations performed.

Their characteristics and the essence of the content are set out in Art. 80 of the Tax Code of the Russian Federation "Tax declaration, calculations" [19].

So, according to clause 1 of the aforementioned norm, a tax declaration is a written statement or a taxpayer's statement drawn up in electronic form. In the latter case, it is transmitted via telecommunication channels with the use of an enhanced qualified electronic signature or through the taxpayer's personal account. However, in any case, the tax return must necessarily contain the following comprehensive information:

- About objects of taxation;

- $\quad$ On income received and expenses incurred;

- About sources of income and about the tax base;

- On tax benefits and on the calculated amount of tax;

- Other data are also subject to transfer, which are intended to serve as the basis for calculating and paying tax.

In turn, in paragraph 3 of Art. 80 of the Tax Code of the Russian Federation provides a complete list of categories of taxpayers and payers of insurance premiums who submit declarations (calculations) in established formats only in electronic form. First of all, these include economic entities, where the average number of employees for the previous calendar year exceeded one hundred people. In such a situation, the relevant information is sent exclusively via telecommunication channels. At the same time, only a Russian organization can be an operator of electronic document flow.

It should be emphasized here that in the overwhelming majority of cases, the legal responsibility of taxpayers occurs precisely for non-compliance with the rules for maintaining, drawing up and submitting reporting documentation. These requirements are enshrined in $\mathrm{Ch}$. 15 of the Tax Code of the Russian Federation "General provisions on liability for the commission of tax offenses".

Now let us touch on the provisions of the act, where public relations in the field of IT application are in direct relationship with civil legal relations.

This is the Federal Law of the Russian Federation of November 27, 2018 No. 422-FZ "On conducting an experiment to establish a special tax regime" Tax on professional income "in the city of federal significance Moscow, in the Moscow and Kaluga regions, as well as in the Republic of Tatarstan (Tatarstan)" [20].

Not only in scientific circles and in the general public, but also in the comments of representatives of various authorities, it immediately acquired a short but unofficial name: "Law on Self-Employed Citizens" (hereinafter Law No. 422-FZ).

The urgency of its adoption is explained by the fact that it Law No. 422-FZ allows to give legal status of taxpayers to individuals who have a regular income from a certain type of activity, but do not pay taxes to the Russian budget. According to some data, their number was 
estimated at about 15 million people, and in some sources a more ambitious figure was called - up to 28 million people. Of course, from the position of the state, this category of citizens, as potential taxpayers, arouses quite intent interest.

At the same time, in the initial period, the promulgation of this act caused a flurry of diametrically opposite conclusions. In various reviews there were both superficial perceptions, and quite objective views on the content and essence of the experimental law.

For example, in the work of Bakaeva considered the prospects for legal regulation of self-employed citizens [21, pp. 3-6]. In another collective publication, Law No. 422-FZ was viewed from various angles. In particular, its positive aspects, innovations were analyzed, and then a critical assessment was given of some provisions that needed additional improvement [22, pp. 96-105].

There are many other opinions on this issue, the meaning and content of which cannot be stated in one article. However, in our opinion, a number of essential factors that characterize Law No. 422-FZ have not received a proper and deep assessment in the already conducted scientific research.

First of all, it contains, although not directly expressed, some elements inherent in contractual relations and regulated by civil law. This position can be confirmed by several arguments.

So, on the basis of the general requirements of the Tax Code of the Russian Federation, all market entities with the status of legal entities, individual entrepreneurs and individuals who are in legally formalized labor relations with employers are taxpayers. They are unconditionally obligated to pay all taxes, fees and insurance premiums established by law.

The state does not enter into any agreements on this matter with the named entities. Meanwhile, with individuals who are subject to the rules of Law No. 422-FZ, the corresponding contacts are formed in a slightly different form. In fact, the state invites them to freely choose the form of behavior, which is most typical for civil legal relations:

- either independently register your type of activity with the tax authorities and pay tax in the amount of four or six percent of the amount of professional income;

- either continue to remain in the shadows with the prospect, sooner or later, to be brought to legal responsibility for carrying out illegal business activities.

In our opinion, these circumstances directly emphasize that the dispositive principles and the method of coordination are an integral feature of a developed, civilized civil society. In this way, a balance of interests is achieved between the power requirements of the state and the numerous requests, rights, benefits and interests of various subjects: citizens and legal entities.

Law No. 422-FZ also contains detailed and detailed provisions that reveal a fairly free procedure for the use of a wide range of IT by self-employed citizens in the field of interaction with domestic tax authorities.

For example, let us turn to the content of Art. 3 - Mobile application "My tax". On the basis of its conditions, at present, such individuals are given the opportunity to register without a personal visit to the tax authorities. This is done by accessing the website of the Federal Tax Service of Russia through a bank or a public services portal. In this case, the person concerned can use a mobile phone, smartphone or computer, including a tablet.

Legal and technological innovation are the rules according to which self-employed citizens no longer need to submit a tax return. Through the specified mobile application, information is transferred about the income received and the expenses incurred when selling goods (works, services, property rights).

According to the information of the Ministry of Finance of the Russian Federation, as of November 1, 2019 , the number of self-employed citizens who entered the official register totaled over 240 thousand people [23]. In turn, their total declared income at the end of the year amounted to more than 32.6 billion rubles, and the amount of calculated tax for the period from the beginning of the experiment in the four above-mentioned regions exceeded 1.07 billion rubles [24].

During 2020, the effect of Law No. 422-FZ was gradually extended to all Russian regions, since even a short experience of application, despite all the claims, proved its viability and social significance.

If we talk about IT as objects of purely civil legal relations, then their individual description in domestic legislation has not yet been presented. The only exceptions are some normative provisions of general purpose.

For example, the list of objects of civil rights set out in Art. 128 of the Civil Code of the Russian Federation, supplemented with a reference to digital rights. In addition, the code itself has recently included Art. 141.1 "Digital Rights". At the moment, they are recognized as obligatory and other rights, the content and procedures for the implementation of which must be determined in accordance with the rules of the information system, and also meet the criteria established by law.

The specificity of this right is that its exercise, distribution, including transfer, pledge, encumbrance in other ways or any restriction in disposal is possible only in the information system without contacting a third party. The holder of digital rights is an individual who, according to 
the rules of the information system, has the ability to dispose of it in full.

In other acts, to a certain extent, developing the provisions of the Civil Code of the Russian Federation, there are also no broad formulations that reveal the meaning of IT, as objects of civil legal relations. So, in Art. 2 of the Federal Law of the Russian Federation of January 12, 1996 No. 7-FZ (as amended on June 8, 2020) "On nonprofit organizations" [25], it is only mentioned that these entities can carry out their activities in the form of distribution using IT about accepted states decisions and policies pursued by the authorities.

On the one hand, the fixation in the Civil Code of the Russian Federation and in other laws of short-term concepts, where, although in an undeveloped form, the indicated innovations are actually recognized as the main object, is quite understandable. Citizens and legal entities are free to conclude any type of contract that is of known interest to them in a particular social sphere. The subjects of the relevant agreements, one way or another, are called upon to be guided by the provisions of various laws, which set out the necessary rules, regardless of the completeness of their content and quality.

On the other hand, the consolidation of clear definitions in laws excludes the emergence of controversial interpretations of certain norms and is designed to raise the technique of legal constructions to a higher level. In our opinion, in the future, the above-mentioned articles need additional and thorough revision.

Nevertheless, regardless of the level of legislative establishments, one's own initiative plays an important role in civil legal relations. In a specific setting, the creative use of scientific and technological achievements can serve as a guarantee of the positive achievement of previously set goals. This applies not only to large economic entities, but also to individual entrepreneurs and ordinary citizens.

As an example of a timely and original approach to solving immediate economic issues using IT, let us name the actions of Sberbank of Russia, which in June 2019 launched the process of electronic registration of a contract for the purchase and sale of housing in the primary real estate market. The first such transaction was carried out using the system of the Unified State Register of Real Estate Objects (EGRON).

As a result, the registration time for this operation was reduced several times. If earlier the corresponding procedure took almost a month, now the buyer receives by e-mail an extract from the above-named register on the transfer of ownership in three to five days from the date of submission of documents.
In addition, the need for the personal presence of the interested person in the registration authorities has disappeared. The specified service is already applied in all regions of our country. Its rules also apply equally to mortgage transactions and cash purchases of real estate.

At the same time, it should be recognized that despite the real achievements, in a number of areas the Russian Federation is still lagging behind the developed states of the world community. At the turn of two centuries, the legal basis for the application of IT in commerce and other areas of economic activity was laid by Directives 2000/31 / EC of the European Parliament and the Council of the European Union "On some legal aspects of information services in the internal market [26].

Almost all members of the community have made due adjustments to the national legislation. However, Germany is the recognized leader in the implementation of IT for various purposes. Currently, ten percent of the German population is employed in those spheres of the economy where the latest scientific developments are actively used, which is twice as high as in our country.

Note that in Germany, the role of the state in financing promising IT-related projects is not paramount. The federal authorities set out their main tasks within the framework of the "High Technologies" strategy, where such areas can be distinguished as: development and adoption of clear legal conditions to stimulate relevant research; comprehensive development of fundamental education; support for private initiatives in high-tech industries within the country and at the international level.

In April 2017, a special meeting of ministers of the G20 countries on the digital economy took place in Germany. Russian representatives also took part in it. Subsequently, the main results of the negotiations were set out in a special document published in Berlin in the autumn of the same year. In our opinion, its content deserves due attention, since many of the ideas contained in it, to a certain extent, can be adapted in our country. First of all, this concerns the legal support of the activities of those sectors of the economy that are directly related to the real increase in the population's income [27].

Despite the difficult international situation, the position of the German industrial giant Siemens AG is indicative. In the field of digital technologies, he successfully cooperates not only with KAMAZ and RAO Russian Railways. The concern also has long-term agreements with Russian universities. These include the St. Petersburg State University, the St. Petersburg State Polytechnic University. In particular, in the latter there is a joint laboratory "Industrial system of artificial intelligence". Individual projects are also being implemented at the Ural State Federal University and in other Russian educational institutions. 


\section{CONCLUSIONS}

All in all, the use of IT and other modern scientific and technological achievements is an expression of the free will of the participants in any transaction permitted by law. The purpose of the innovations is to objectively meet the numerous substantive requests of citizens and legal entities, as well as the real state of affairs in various spheres of social life.

An analysis of the cardinal changes and additions made to the Tax Code of the Russian Federation in recent years shows: in the field of IT implementation, it is the most progressive, domestic regulatory legal act, because it contains clear, detailed provisions defining the procedure for the comprehensive use of computer technology, communications and systems telecommunications.

Furthermore, the lack of a single concept of "digitalization" is not an obstacle for a correct, unbiased and comprehensive assessment of the actual order of things related to the use of IT in various areas of public and state interests, as well as contacts and relationships of legal entities and citizens.

At the same time, it would be logical to supplement Art. 128 of the Civil Code of the Russian Federation with a specific indication that IT, as well as other means of computer technology, communications and telecommunication systems are the object of civil rights, along with other numerous objects provided for by the provisions of the Civil Code of the Russian Federation.

Overall, the creative, legally formalized borrowing of legal, scientific, technical and other developments available in the arsenal of other subjects of the world community, in its essence, is intended to enrich both Russian legal science and the current practice of widespread use of the information technologies.

\section{REFERENCES}

[1] Art. 5 of the Federal Law of the Russian Federation of July 27, 2006 No. 149-FZ (as amended on June 8, 2020) "On Information, Informatization and Protection of Information"

[2] The Federal Law of the Russian Federation of January 10, 2002 No. 1-FZ "On electronic digital signature".

[3] Federal Law of the Russian Federation dated April 6, 2011 No. 63-FZ (as amended on June 8, 2020) "On electronic signature", and the previous one lost its legal force.

[4] A.P. Yershov, Informatizatsiya: ot kompyuternoy gramotnosti uchaschikhsya $\mathrm{k}$ informatsionnoy kulture obschestva, Kommunist 2 (1988) 82-92.

[5] A.N. Shvetsov, Informatsionnoye obschestvo, Teoriya I praktika stanovleniya $\mathrm{v}$ mire I v Rossii, KRASAND, 2011, 277 p.

[6] A.V. Babkina, Tendentsii razvitiya ekonomiki I promyshlennosti $\mathrm{v}$ usloviyakh tsifrovizatsii, SPbSTU, 2017, 658 p.

[7] L.B. Lapidus, Tsifrovaya ekonomika: upravleniye elektronnym biznesom I elektronnoy kommertsiyey, INFRA-M, 2019. 479 p.

[8] D.G. Burtsev, Problemy sovershenstvovaniya nalogovogo administrirovaniya, SPb Tsentr podgotovki personala federalnoy nalogovoy sluzhby, 2007, 164 p.

[9] A.V. Bobrov, Novye informatsionnye tekhnologii: nekotorye gumanitarnye aspekty, Obschestvo I pravo 2(20) (2008) 268-270.

[10] K.A. Pisenko, E.G. Gasparyan, Aktualnye voprosy pravovogo obespecheniya antimonopolnoy politiki na tsifrovykh finansovykh rynkakh, Finansovoye pravo 8 (2018) 34-38.

[11] L.V. Sannikov, Yu.S. Kharitonova, Tsifrovye aktivy kak obyekty predprinimatelskogo oborota, Pravo I ekonomika 4 (2018) 27-34.

[12] A.A. Nevskaya, A.V. Kondeev, Regulirovaniye elektronnoy torgovli $\mathrm{v}$ evraziyskom prostranstve, Rossiyskiy vneshneekonomicheskiy vestnik 2 (2019) 59-71.

[13] O.A. Serova, Robots as Digital Economy Participants: Issues of Legal Nature Determination, Civil Law 3 (2018) 22-24. DOI: https://doi.org/10.18572/2070-2140-2018-3-2224

[14] K. Nam, Elektronnaya forma sdelki v prave Evropeyskogo Soyuza I Germanii, Khozyaystvo I pravo 2 (2019) 118-128.

[15] A.S. Akhmetov, K voprosu ob ispolzovanii informatsionnykh tekhnologiy v yuridisheskom obrazovanii, Pravo I obrazovaniye 10 (2017) 71-78.

[16] The "Strategy for the Development of the Information Society in the Russian Federation for 20172030", approved by Decree of the President of the Russian Federation No. 203 dated May 9, 2017

[17] Dictionary of foreign words in Russian, YUNVES, 1996, 832 p.

[18] The newspaper “Accounting. Taxes. Law" (2019) https://www.gazeta-unp.ru/news/20586-fns-soobshchila-skolko-sobrala-nalogov-v-2018-godu Accessed 20 Oct 2020 
[19] Art. 80 of the Tax Code of the Russian Federation "Tax declaration, calculations"

[20] The Federal Law of the Russian Federation of November 27, 2018 No. 422-FZ "On conducting an experiment to establish a special tax regime" Tax on professional income"

[21] O.Yu. Bakaeva, Perspektivy pravovogo regulirovaniya samozanyatykh grazhdan, Nalogi 5 (2018) 3-6.

[22] A.A. Gogin, G.N. Gogina, V.G. Medvedev, Eksperimentalny zakon: pozitivnye aspekty, innovatsii I kriticheskiye otsenki, in: Sbornik statey Vserossiyskoy nauchno-prakticheskoy konferencii "Problemy nauchnoprakticheskoy deyatelnosti, perspektivy vnedreniya innovatsionnykh resheniy, OMEGA SCIENCE, Ufa, 2019, pp. 96-105.

[23] Ministry of Finance (2019) https://minfin.gov.ru/ru/press-center/ Accessed 20 Oct 2020

[24] Rambler Finance (2019) https://finance.rambler.ru/money/43201518-glava-fns-samozanyatyezadeklarirovali-dohod-32-6-milliarda-rubley/ Accessed 20 Oct 2020

[25] Art. 128 of the Civil Code of the Russian Federation, supplemented with a reference to digital rights. In addition, the code itself has recently included Art. 141.1 "Digital Rights"

[25] Art. 2 of the Federal Law of the Russian Federation of January 12, 1996 No. 7-FZ (as amended on June 8, 2020) "On non-profit organizations"

[26] Directive 2000/31 / EC of the European Parliament and the Council of the European Union "On some legal aspects of information services in the internal market". http: / www. eurasiancommission.org. Accessed $10 \mathrm{Sep}$ 2020

[27] Federal Ministry for Economic Affairs and Energy (2017) First steps by the G20 towards the implementation of the Roadmap Adopted 7 April 2017 in Dusseldorf. Berlin, 27 November. 2017. https://www.bmwi.de/Redaktion/DE/Downloads/G/g20-taetigkeitsbericht-digitalministertreffen2017.pdf?_blob=publicationFile $\& \mathrm{v}=8$ Accessed 17 Oct 2020 